\title{
Carl Schmitt's defence of sovereignty
}

\author{
LARS VIN X
}

H. L. A. Hart once remarked that a sovereign, according to the classical doctrine of sovereignty, is 'as essential a part of a society which possesses law, as a backbone is of a man'. ${ }^{1}$ Not least as a result of Hart's own attack on Austin's theory of sovereignty, analytical legal theorists today agree that a sovereign is not just unnecessary for but incompatible with the existence of legal order. To explain the variety and persistence of legal norms, the continuity of legal order and the evident possibility of legal constraints on legislative power, so goes the contemporary legaltheoretical consensus, legal order must be regarded as rule-based. As a result, sovereignty can at best be an office defined by positive law. There can be no meta-legal, purely political power which is legally illimitable and yet functions as the source of all positive law. ${ }^{2}$

Nevertheless, the doctrine of sovereignty is not without its contemporary defenders. The authors in question, though, rarely address the legaltheoretical worries about sovereignty head on. Rather, they argue that sovereignty is essential to the legitimacy of a modern democratic constitution. To be democratically legitimate, a constitution must, it is argued, be the product of an exercise of a constituent power which is prior to all positive law (including positive constitutional law) and which functions as the legitimating source of all positive legality. ${ }^{3}$

1 H. L. A. Hart, The Concept of Law (Oxford University Press, 1961), 49.

2 See Hart, Concept of Law, 18-76; Joseph Raz, The Concept of a Legal System: An Introduction to the Theory of Legal System (Oxford University Press, 1970), 27-43; Pavlos Eleftheriadis, 'Law and Sovereignty', Law and Philosophy, 29 (2010), 535.

3 See, e.g., Dieter Grimm, Souveränität. Herkunft und Zukunft eines Schlüsselbegriffs (Berlin University Press, 2009), 99-123; Olivier Beaud, La puissance de l'état (Paris: Presses Universitaires de France, 1994), 199-491; Andreas Kalyvas, Democracy and the Politics of the Extraordinary. Max Weber, Carl Schmitt, and Hannah Arendt (New York: Cambridge University Press, 2008); Martin Loughlin, Foundations of Public Law (Oxford University Press, 2010); Paul W. Kahn, Political Theology: Four New Chapters on the Concept of Sovereignty (New York: Columbia University Press, 2011). 
However, if the doctrine of sovereignty conflicts with key features of legal order, a constitutional theory based on the concept of sovereignty must be flawed. And if the idea of a sovereign authority as the source of legal order cannot possibly make any sense, we will have to let go of the claim that a constitution must be legitimized by reference to constituent power. Those who want to hold on to the notion of sovereignty because they think it essential to a democratic constitutional theory must first establish that the concept of sovereignty is jurisprudentially meaningful.

Carl Schmitt's theory of sovereignty is the obvious place to look for a defence of the continuing jurisprudential relevance of the concept of sovereignty. Schmitt's famous definition of sovereignty - sovereign is he who decides on the state of exception ${ }^{4}$ - offers a surprisingly sophisticated response to the legal-theoretical challenge to sovereignty. Schmitt managed to show, I will argue, that the presence of a legally illimitable sovereign whose decisions condition the applicability of law is not incompatible with the existence of rule-based legal order. Still, Schmitt's theory of sovereignty falls short of a full rehabilitation of the classical doctrine of sovereignty. His argument does not establish that a sovereign is as necessary to law as a backbone is to a man. Like his contemporary followers in constitutional theory, Schmitt claims instead that a sovereign is necessary for the existence of a legitimate legal order. ${ }^{5}$

To assess Schmitt's theory of sovereignty, as well as contemporary efforts to defend the relevance of sovereignty for democratic constitutional theory, we therefore have to ask whether there is good reason to hold that a legal order can only be legitimate if it derives from a sovereign power above the law. I will argue that there is not. Schmitt's defence of sovereignty, despite its partial success against the legal-theoretical criticism of sovereignty, is therefore a theoretical dead end.

\section{The positivist challenge to sovereignty}

To sharpen our understanding of the aims of Schmitt's defence of sovereignty, it will be helpful to take a brief look at the discussions of

${ }^{4}$ Carl Schmitt, Political Theology: Four Chapters on the Concept of Sovereignty (University of Chicago Press, 2005), trans. George Schwab, 5.

${ }^{5}$ Hasso Hofmann, Legalität gegen Legitimität. Der Weg der politischen Philosophie Carl Schmitts, 4th edn. (Berlin: Duncker \& Humblot, 2002); David Dyzenhaus, Legality and Legitimacy: Carl Schmitt, Hans Kelsen and Hermann Heller in Weimar (Oxford University Press, 1997), 38-101. 
sovereignty with which Schmitt engaged. Hobbes' theory of sovereignty, which Schmitt presented himself as wanting to revive, is the natural starting point for such an inquiry.

Hobbes' claims about sovereignty arise from a reflection on the nature and function of the state. Hobbes insists that the state will be able to provide peace and security to its subjects only if all its powers are united in the hands of one person or one group of persons. Any form of separation or division of powers, in Hobbes' view, would raise the danger of an irresolvable conflict between different organs of state. ${ }^{6}$ Hobbes, moreover, puts emphasis on the claim that the sovereign is not legally accountable to his subjects in any way. Not being a party to the social contract, the sovereign cannot rightfully be deposed, accused of injustice in a court of law or punished. ${ }^{7}$

It would nevertheless be mistaken to conclude that the powers of Hobbes' sovereign are legally unlimited. Throughout Leviathan, Hobbes repeatedly emphasizes the claim that the sovereign, as a mere representative of the state, lacks the legal power to alienate any of the essential rights of sovereignty. In particular, Hobbes is very anxious to emphasize the point that a sovereign cannot possibly be legally bound by decisions of previous sovereigns which appear to have granted away sovereign powers, such as the power to tax without seeking consent. Any such grant, in Hobbes' view, is to be regarded as void unless it went along with an explicit renunciation of sovereignty. ${ }^{8}$ Sovereignty, for Hobbes, is ultimately an attribute of the state, not a private possession of the sovereign person.

The inalienability of sovereign power in Hobbes illustrates an important feature of Hobbes' theory of the state, a feature which is also evident in the claim that one can draw up a list of essential powers of sovereignty or in the claim that no system of government can possibly accommodate a separation of powers and still fulfil its purpose. In Hobbes' view, the social institution which we call the state has an essence or nature which is determined by its function. The function of the state is to provide peace and security to its members by ending the state of nature between them

6 Thomas Hobbes, Leviathan (Cambridge University Press, 1996), ed. Richard Tuck, 127.

7 Ibid., 121-9.

8 Ibid., 127, 153, 222. For some recent work affirming the importance of the rule of law for Hobbes, see Chapters 6-10 in David Dyzenhaus and Thomas Poole (eds.), Hobbes and the Law (Cambridge University Press, 2012); Perez Zagorin, Hobbes and the Law of Nature (Princeton University Press, 2009) 84-98; Larry May, Limiting Leviathan: Hobbes on Law and International Affairs (Oxford University Press, 2013). 
and by protecting them against external enemies. Any institution which is to serve this purpose with a degree of success must, according to Hobbes, instantiate the constitutional framework put forward in Leviathan. The sovereign is therefore legally limited by what one might call a 'constitution in natural law'. There are certain actions - such as the granting away of essential rights of sovereignty - which a sovereign, though unpunishable, cannot validly perform.

The idea of a constitution in natural law allowed Hobbes to argue that there is no conflict between the claim that sovereignty is an attribute of the state, and thus an essentially public power, and the claim that the existence of legal order requires that there be a sovereign person whose decisions are the sole source of and unbound from all positive law. The constitution in natural law turns sovereignty into a representative and public role defined by natural law, even while shielding it from any limitation grounded in positive law.

Hobbes' theory of sovereignty, however, is clearly no longer tenable. It is motivated by the view that a stable state and a functioning legal order require an extreme concentration of political power. But we now know that states as well as legal systems can exist and be stable without being represented and protected by a sovereign authority which stands above the positive law and which concentrates all political power in its hands. If there is such a thing as a constitution in natural law, an institutional framework which must be instantiated by every functioning state, then Hobbes clearly gave much too narrow a description of it.

Hart's attack on the doctrine of sovereignty can be understood as one possible reaction to this failure of Hobbes' project. Hart, taking his cues from Austin, took the doctrine of sovereignty to claim that wherever there is a legal system, there must be a sovereign person whose legislative decisions are the sole source of law. This view, understandably, no longer made any sense to Hart, given the undoubted existence of modern legal systems which do not contain a sovereign legislator. Austin, in reducing sovereignty to a mere de facto power, had already uncoupled sovereignty from natural law. ${ }^{9}$ This allowed Hart, who attacked the doctrine of sovereignty in the form which it had been given by Austin, to argue that the attempt to ground law in sovereignty must fail to explain the continuity of the legal system, the diversity of legal norms and the normativity of

9 John Austin, The Province of Jurisprudence Determined (Cambridge University Press, 1995), ed. Wilfrid E. Rumble, 18-37, 164-83 and 211-29. 
law. Hart, consequently, rejected the doctrine of sovereignty altogether and replaced it with the theory of the rule of recognition..$^{10}$

Hans Kelsen reacted somewhat differently to the breakdown of the Hobbesian view by adopting a depersonalized reading of the doctrine of sovereignty. Sovereignty, according to Kelsen, is to be understood not as the unlimited power of a person or group of persons but rather as the normative independence of a legal system. What we really mean to convey when we say that a state is sovereign, according to Kelsen, is that the state's law is not derived from any higher source than its own basic norm. ${ }^{11}$

Kelsen, like Hobbes, was interested in the question how it is possible to attribute actions performed by individual human beings to the state and argued that such attribution requires a legal basis. But, since Kelsen rejected the idea of a constitution in natural law, he held that the legal basis for the attribution of individual acts to the state must be sought in positive law. Purported acts of state amount to genuine exercises of public power, according to Kelsen, only if they are properly authorized by positive law. The state, like the sovereign of old, is unable to do wrong; it can act only in the medium of legality. The sovereignty of the state, in the last analysis, thus turns out to be equivalent to the autonomy of positive law. Though the state is, in a sense, properly called 'sovereign', there can be no person or group of persons who act in the name of the state but whose competence is essentially incapable of limitation by positive law. ${ }^{12}$

For our purposes, the differences between Hart's and Kelsen's treatment of the classical doctrine of sovereignty matter less than the commonalities. Both Hart and Kelsen deny that there could be a personal, meta-legal sovereign authority which creates all positive law while being unbound from it. They both concede, of course, that a positive legal system could be structured in such a way as to confer wide-ranging, even materially unlimited powers of law-making on one person or group of persons. However, such a power could not, in either approach, be regarded as being a transcendent source of positive law. Its authority would depend, rather, on the contingent content of a particular rule of

${ }^{10}$ Hart, The Concept of Law, 18-76.

11 Hans Kelsen, Das Problem der Souveränität und die Theorie des Völkerrechts. Beitrag zu einer reinen Rechtslehre (Tübingen, Germany: J. C. B. Mohr (Paul Siebeck), 1920), 1-101.

12 For an overview of Kelsen's development of these themes, see Lars Vinx, Hans Kelsen's Pure Theory of Law: Legality and Legitimacy (Oxford University Press, 2007), 78-100. 
recognition or basic norm. ${ }^{13}$ All public powers, in other words, must be grounded in antecedent positive law.

Schmitt, like Hart and Kelsen, no longer supports the Hobbesian notion of a constitution in natural law. He agrees that all law is positive. Hence, he does not think that the public role of sovereign can be defined in terms of a constitution in natural law. Nevertheless, he wants to hold on to the view that legal order is, or at least ought to be, based on an extra-legal sovereign authority. We can now describe the challenge which Schmitt had to face in developing his defence of sovereignty with greater precision. Schmitt had to show that there is a way to conceive of positive law as being grounded in the decisions of a sovereign person who stands above the positive law while being unbound from it and he had to do so without taking resort to the notion of a constitution in natural law.

\section{Sovereignty as the power to decide on the exception}

At first glance, the chances of meeting this challenge appear slim. To meet the challenge, one will have to deny - in order to avoid the legalist implications of Kelsen's analysis - that sovereignty is an attribute of a legal system or of a legally constituted state. One will have to conceive of sovereign authority, instead, as an attribute of a particular individual or group. The only way to do this, presumably, is to understand sovereignty not as a legal competence but as an overwhelming de facto power of that individual or group to compel obedience. But then one will have to face the criticisms which Hart levelled against Austin. If it is the mere possession of de facto power to issue general commands and to compel obedience which endows a person or group of persons with sovereign authority, it will become impossible, if Hart's argument against Austin is sound, to explain the continuity of the legal system, the diversity of legal norms and the internal normativity of law. It seems that sovereignty must either succumb to legality or remain altogether unrelated to legal order.

Schmitt avoids the first horn of this dilemma by conceiving of sovereignty in purely personal terms. His definition of sovereignty states that the sovereign is he who decides on the state of exception. ${ }^{14}$ This defines sovereign authority as the power to take a decision on the exception. In addition, the definition carries the implication that sovereignty must

\footnotetext{
13 See Hart, Concept of Law, 66-8; Kelsen, Das Problem der Souveränität, 27.

14 Schmitt, Political Theology, 5.
} 
inhere in a particular individual or group. If there is to be a sovereign, there must be a real or concrete will capable of taking an actual decision on the exception. A rule-based, impersonal institution cannot be the primary bearer of sovereignty. The power of sovereignty, according to Schmitt, ultimately belongs to him or to them who can in fact take the decision on the exception, not to a legally constituted artificial person of the state which is merely represented by a sovereign. ${ }^{15}$

Schmitt explicitly argues that the power to take a decision on the absolute exception is not to be understood as a power conferred by law but rather as a de facto power. Constitutional law, to be sure, may contain acknowledgements of the existence of such a power (or it might, for that matter, try to deny the existence of such a power), but the power exists wherever there is someone who can in fact take a decision on the total exception, and it is not bound to any legal form. ${ }^{16}$ It is a misinterpretation of Schmitt's definition of sovereignty to read it as though it claimed that one ought to look to who is made competent by a positive constitution to decide on the state of emergency to find out who is sovereign. The existence of such a constitutional provision, for Schmitt, is neither a necessary nor a sufficient condition for sovereignty: it is not necessary because there obviously may be an agency that can bring about a decision on the total exception even without being formally authorized to do so. It is not sufficient because constitutional emergency provisions, for rather obvious reasons, will typically fail to confer a power to declare an absolute exception. Their usual aim, after all, is to tame and domesticate the power to decide on the exception. ${ }^{17}$ What is more, the claim that Schmittian sovereignty is a competence conferred by a positive

15 To be sure, Schmitt suggests, in Political Theology, that sovereignty is an attribute of the state. For instance, he says that in the state of absolute exception, 'the state remains, whereas law recedes' and that it is 'the state that suspends the law' (Ibid., 12). But the term 'state', in this context, cannot refer to an institution structured by any kind of law if, as Schmitt makes clear, the decision on the exception is at least potentially a decision that suspends absolutely all law, perhaps with the view of establishing an altogether new constitution. In his Constitutional Theory, Schmitt defines the state as 'the political unity of the people', which manifests itself in legally unregulated acts of constituent power. See Carl Schmitt, Constitutional Theory (Durham, NC: Duke University Press, 2008), trans. Jeffrey Seitzer, 75. Schmitt's talk of the state, then, is perhaps best understood as referring to a Schmittian political community, that is, to a group of people united only by a shared disposition to distinguish between friend and enemy in the same way. See Carl Schmitt, The Concept of the Political. Expanded Edition (University of Chicago Press, 2007), trans. George Schwab, 19-25. However, to call such a group a state is misleading at best, if it is essential to the state to be an artificial person or an organized community.

16 Schmitt, Constitutional Theory, 125-35. ${ }^{17}$ Schmitt, Political Theology, 12. 
constitution also conflicts with Schmitt's theory of popular sovereignty. If the people are to be sovereign, and if popular sovereignty is to be understood as an inalienable power of constitution-making, then popular sovereignty (or sovereign dictatorship exercised on behalf of the people) cannot be a power or a competence conferred by a positive constitution. ${ }^{18}$

Note as well that the power to take a decision on the total exception is not a legislative or adjudicative authority. It does not create legal norms or modify legal relationships between legal persons. Neither does it apply norms. All it does, so to speak, is to switch the law as a whole on and off. ${ }^{19}$ Despite its nature as a de facto power, however, the power to take a decision on the total exception is a power that affects the law: it conditions the law's applicability. The decision on the exception, then, is

18 Martin Loughlin claims that when Schmitt's sovereign takes a decision on the exception, 'positive law recedes, but droit politique remains' (Loughlin, Foundations of Public Law, 401). He goes on to argue (Ibid., 402) that droit politique is manifest, for instance, in the fact that 'in the Weimar Republic that power [to take a decision on the exception] was vested in the president under Article 48 of the Constitution, a common arrangement under modern constitutions'. Schmitt, however, denies that the dictatorship of the president under Article 48 is a power of sovereignty precisely because the former, but not the latter, is a competence allocated (and limited) by positive constitutional law. See Carl Schmitt, 'The Dictatorship of the President of the Reich According to Article 48 of the Weimar Constitution', in Schmitt, Dictatorship: From the Origin of the Modern Concept of Sovereignty to Proletarian Mass Struggle (Cambridge, UK: Polity Press, 2014), trans. Michael Hoelzl and Graham Ward, 180-226. Hence, the positive constitutional rules which confer circumscribed powers of dictatorship to a president (or some other constitutional office) cannot be the order that Schmitt, in Political Theology, claims will remain even in a state of total exception. What remains in the state of total exception, according to Schmitt, is not a legal order but the distinction between friend and enemy. In George Schwab's translation of Political Theology, Schmitt is made to say, on p. 12, that in a state of exception 'order in the juristic sense still prevails, even if it is not of the ordinary kind'. However, what Schmitt really wrote (in my translation) is that 'since the state of exception is still something other than a mere anarchy or chaos, an order in the juristic sense still exists, though not a legal order'. See Carl Schmitt, Politische Theologie. Vier Kapitel zur Lehre von der Souveränität, 7th edn. (Berlin: Duncker \& Humblot, 1996), 18: 'Weil der Ausnahmezustand immer noch etwas anderes ist als eine Anarchie oder ein Chaos, besteht im juristischen Sinn immer noch eine Ordnung, wenn auch keine Rechtsordnung. What Schmitt wants to say here is clear enough. What still exists in the state of exception is the state, understood as a political community (see the discussion in note 15), which, according to Schmitt, is a subject of juristic thought, but not the law, political or otherwise. Schwab's translation simply drops Schmitt's explicit statement that there is no longer a legal order in the state of exception. Loughlin's view that, according to Schmitt, 'droit politique remains' in the state of exception appears to be based on Schwab's incomplete translation. See Loughlin, Foundations of Public Law, 401.

19

Schmitt, Political Theology, 12. 
jurisprudentially relevant, even though it does not legislate or adjudicate. Every ordinary application of the law, according to Schmitt, presupposes a prior decision to the effect that the situation is normal and not exceptional and that it is therefore possible and appropriate to rely on legality for the solution of social conflict. ${ }^{20}$

These observations explain how Schmitt avoids the second horn of the dilemma outlined earlier. Hart's attack on Austin's notion of sovereignty is an attack on the claim that a mere de facto power can become the source of all positive legal norms by assuming the role of an uncommanded commander. Schmitt, however, is clearly not guilty of the mistake of conceiving of laws as sovereign commands. A sovereign who does not legislate obviously does not issue commands which claim legal authority. Hart convincingly argues that Austin's conception of a sovereign legislator fails to explain the continuity of legal system, to account for the diversity of legal norms and to explain the internal normativity of legal rules. But since Schmitt's sovereign is not a legislator and does not enact positive legal norms, Schmitt's theory simply is not vulnerable to the objections that Hart levelled against Austin.

Let me explain these claims in a little more detail. Schmitt's sovereign is perfectly able to coexist, in times judged non-exceptional, with a working positive constitutional order, perhaps even a liberal-democratic one. ${ }^{21}$ Such an order would determine a procedure of legislation for the production of legal norms, norms which, in turn, guide the activity of the courts and of administrative agencies. Hence, no positive legal norm, under circumstances of normality, need be validated by recourse to sovereign authority. A norm's validity, rather, will rest on the fact that it has been enacted in accordance with the rule of recognition determined by the constitution. Since there is no need for Schmitt to portray positive laws so validated as commands, his theory is well able to accommodate Hart's rule-centred description of the legal system.

Of course, Schmitt argues that the operation of the legal system presupposes that the sovereign judges the general situation to be nonexceptional so that law can apply. He also takes it that legal norms, though validly enacted, will not apply as long as the sovereign judges the situation to be exceptional. Thus, perhaps a Hartian might argue that there is still room for a continuity puzzle of the sort which Hart deploys against Austin to arise. Imagine that the sovereign suspends legality

20 Ibid., 12-3. ${ }^{21}$ Schmitt, Constitutional Theory, 145-6. 
altogether, in a global state of emergency, and that legality is later reestablished, after the sovereign, through the use of de facto force, has managed to produce a situation which he judges to be normal. Should we say that the legal system after the state of emergency is the same as the one which was in force before the emergency? Or should we say that a new legal system has been created? Questions of this sort will not embarrass Schmitt, for the simple reason that Schmitt will answer such questions in line with the criteria which a Hartian would apply to judge of questions of continuity.

A sovereign's actions in a state of exception, presumably, could lead to two different results. A sovereign might re-establish the social condition which underpinned the old constitution so as to make it possible, once again, to apply the law of the old constitution. Otherwise, a sovereign's actions could lead to the establishment of a new constitution. This, presumably, will happen if the old constitution has been made obsolete by social change so that it is no longer possible to preserve the condition of normality which underpinned it. In the first of these two scenarios, Schmitt would claim that there is legal continuity, while he would deny continuity in the second. ${ }^{22}$ Hart will arrive at exactly the same result because, in the first case, judges and officials are going to continue to apply the old rule of recognition, while in the second they will follow a new rule.

Let me draw a preliminary conclusion of our discussion of Schmitt's theory of sovereignty so far. Schmitt's theory of sovereignty seems to offer a coherent response to the legal-theoretical claim that a sovereign authority above the positive law, an authority which conditions the law's applicability, is incompatible with a continuous, rule-based legal order. However, Schmitt's argument clearly does not establish that a meta-legal sovereign authority is as necessary to the existence of legal order as a backbone is to a man. There would appear to be no good reason to deny that a society characterized by the absence of a Schmittian sovereign could have a functioning rule-based legal system. Schmitt, then, has fought the legal-theoretical criticism of sovereignty to a standstill. But where does that leave us?

It is crucial to Schmitt's argument, as we have seen, that the power of deciding on the exception - though it is not legislative or adjudicative be seen as a power which conditions the applicability of positive law.

22 Of course, Schmitt thinks that the continuous existence of political community is not tied to legal continuity. See ibid., 140-6. 
If sovereign power is not interpreted as conditioning the applicability of positive law, Schmitt's conception of sovereignty risks becoming purely political and jurisprudentially irrelevant.

A Kelsenian would press Schmitt on precisely this point. The Kelsenian will admit that a society might contain a person or group of persons who have a de facto power altogether to suspend legality, to completely interrupt the normal operation of the law. But why should this fact be jurisprudentially significant? As long as the law does not recognize the power to take a decision on the exception, the existence of that power, or its successful exercise, will be no more than a mere fact of political sociology. In making this claim, one does not have to deny that politically powerful groups attempt, from time to time, to interrupt the application of law and that they sometimes succeed in breaking legal continuity. Neither does one have to contest that a legal system can exist and operate only where it is sufficiently effective, that is, where its operation is not successfully challenged by de facto powers aiming to suspend or block its application. If the view that the power to take a decision on the exception conditions the applicability of law boils down to the banal insight that law must be sufficiently effective to exist, how can that power be portrayed as any kind of legal power, as a power which is of jurisprudential concern?

To meet this challenge, Schmitt adds an important qualification to the view that the sovereign decision conditions the applicability of law. $\mathrm{He}$ claims that it is the legitimate applicability of the norms which belong to some positive legal system which presupposes a sovereign who can decide on the exception. ${ }^{23}$ This response, if defensible, opens a way out of the impasse we just pressed on Schmitt. The power to take a decision on the exception obviously must be regarded as jurisprudentially relevant if the existence of that power is a necessary condition of the legitimate applicability of positive law. But, of course, Schmitt will now have to explain why a sovereign who can take a decision on the exception is necessary for the existence of legitimate positive law.

Schmitt's answer to this question, in a nutshell, is that the sovereign's decision on the exception expresses the political existence of a people. The sovereign decision, in other words, is the only form in which popular sovereignty can be actualized, and popular sovereignty, Schmitt argues, is

23 Ibid., 136; Carl Schmitt, Legality and Legitimacy (Durham, NC: Duke University Press, 2004), trans. Jeffrey Seitzer. 
the only modern basis for the legitimacy of law. ${ }^{24}$ It is the assessment of this normative claim to which we must turn to resolve the standoff.

\section{Schmitt on sovereignty and the legitimacy of legal order}

Schmitt's claim that a sovereign authority is necessary to secure the legitimate applicability of law makes a first appearance, at least implicitly, in Schmitt's early work, Gesetz und Urteil, which was published in $1912 .^{25}$ In this book, Schmitt is concerned to outline the conditions of legal determinacy in judicial decision-taking. The starting point of the argument is a rejection of a formalist picture of adjudication. The application of statutes to particular cases by the courts, Schmitt argues, cannot be portrayed as a process of logical deduction in which general statutory rules clearly determine their applicative instances. Rather, application will, in many instances, require a judgement to the effect that a case can be brought under a concept, a judgement which is not itself guided by the legal rule which is to be applied. ${ }^{26}$

Schmitt does not think, however, that the rejection of formalism should lead a judge to embrace the self-conscious use of judicial authority as an instrument of social reform. Schmitt holds that judicial decisiontaking is legitimate only as long as it does not depend on potentially controversial moral or political judgements on the part of the judge. ${ }^{27}$ The fact that legal determinacy cannot be ensured by a judicial commitment of fidelity to statute does not imply, in Schmitt's view, that legal determinacy cannot be achieved at all. Judicial practice, Schmitt claims, has developed an alternative means of ensuring legal determinacy: a shared sense of appropriateness, grounded in the common educational background of legal officials, in the common experiences of those who hold judicial office and in the convergent ethical assumptions of members of the judiciary. ${ }^{28}$

If it is the social homogeneity of the judiciary which ensures legal determinacy, and if legal determinacy is desirable, we will have to conclude that a justifiable judicial decision is one which conforms to the expectations of other legal officials. This is why Schmitt claims that a

24 Schmitt, Constitutional Theory, 126-30.

${ }^{25}$ Carl Schmitt, Gesetz und Urteil: Eine Untersuchung zum Problem der Rechtspraxis, 2nd edn. (München: C. H. Beck, 1969).

${ }^{26}$ Ibid., 21-43. ${ }^{27}$ Ibid., 42, $99 . \quad{ }^{28}$ Ibid., 68-114. 
legal decision is correct if and only if we can assume that another judge would have taken the same decision. ${ }^{29}$

Schmitt's argument in Gesetz und Urteil does not yet explain why legal determinacy is desirable - so desirable, in fact, as to be declared the sole basis of a standard of the correctness of judicial decision. It is possible, however, to gather an answer to this question from Schmitt's later works. A legal decision not determined in advance by a shared practice would amount to an instance of domination or, as Schmitt prefers to put the point, to a form of 'indirect rule'. ${ }^{30}$

The authority and institutional independence of the judiciary, Schmitt insists, depends on the presupposition that it does no more than to apply the law. A judge who takes decisions conditioned by his or her personal moral or political judgement, under the guise of applying the law, exercises a form of arbitrary and unaccountable political rule. Not surprisingly, Schmitt harbours a strong suspicion against judicial review. ${ }^{31}$ At the same time, though, he argues that an unrestrained parliamentary legislator is in danger of becoming a mere instrument of the illegitimate rule of partial interests which have found ways to corrupt the legislature. ${ }^{32}$ From Schmitt's point of view, both the fundamental positions in contemporary normative constitutional theory - a rights-oriented constitutionalism arguing for judicial review and a political constitutionalism concerned with protecting the democratic legislature from judicial interference - fall equally short of preventing domination.

The reason, according to Schmitt, is that both positions overlook the importance of legal determinacy as a condition of the legitimate applicability of law, including constitutional law. Liberal constitutionalism will have to admit that judicial decisions which enforce constitutional rights have the character of un-democratic judicial impositions as they will often turn out to be controversial, unexpected and not grounded in an

29 Ibid., 68-9.

30 See for the notion of 'indirect rule', Carl Schmitt, The Leviathan in the State Theory of Thomas Hobbes: Meaning and Failure of a Political Symbol (University of Chicago Press, 2008), trans. George Schwab and Erna Hilfstein, 65-77.

31 Carl Schmitt, The Guardian of the Constitution, part I, in The Guardian of the Constitution: Hans Kelsen and Carl Schmitt on the Limits of Constitutional Law (Cambridge University Press, 2014), trans. Lars Vinx, 79-124; Carl Schmitt, 'Das Reichsgericht als Hüter der Verfassung' in Schmitt, Verfassungsrechtliche Aufsätze aus den Jahren 1924-1954 (Berlin: Duncker \& Humblot, 1958), 63-109.

32 See Carl Schmitt, The Crisis of Parliamentary Democracy (Cambridge, MA: MIT Press, 1985), trans. Ellen Kennedy, 33-50; Schmitt, Hüter der Verfassung, 73-91; Schmitt, Legality and Legitimacy, 17-36. 
established judicial practice which is already accepted as appropriate by the community at large. ${ }^{33}$ Political constitutionalism, or what Schmitt calls the legislative state, ${ }^{34}$ must own up to the fact that parliamentary decision-taking, especially in a pluralist society, need not reflect the will of the people and that it may well come to benefit partial interests over the common good. In either case, the appeal to the constitutionality of the decision - be it judicial or legislative - is merely going to paper over the fact that genuine democratic self-determination remains unrealized.

Schmitt does not hold that such a failure of self-determination is an inevitable result of judicial review or of parliamentary legislation. However, if there is no failure, he argues, the reason must be that the judicial or legislative decision takes place in the context of a shared social understanding of what is appropriate that makes decisions both expectable and acceptable. Legal determinacy, in other words, indicates the absence of conflict between social groups and hence the absence of domination of one social group by another. Determinacy, however, is based on the presupposition of social homogeneity, a presupposition which cannot be taken for granted under modern social conditions and which cannot be guaranteed or protected by the law itself. ${ }^{35}$ Once a decision is controversial, we must conclude that determinacy, as the condition of the legitimate applicability of the law, no longer obtains. And whenever the condition of homogeneity is unfulfilled, decisiontaking under legal or constitutional procedures must turn out to be dominating to some. The rule of law will become an instrument of the indirect rule of a part over the whole and veil it at the same time. Where decisions which take place within the constitutional system have become deeply controversial, social homogeneity must first be restored to make the law legitimately applicable. This restoration, Schmitt argues, requires a sovereign decision on the exception as well as dictatorial action in the state of exception. ${ }^{36}$

We already know what the sovereign decision on the exception does. It declares the law as a whole to be non-applicable. As Schmitt makes clear, the decision on the exception thereby opens the space for a sovereign dictatorship which operates without any legal restraints of any kind and

${ }^{33}$ Carl Schmitt, 'Grundrechte und Grundpflichten' in Schmitt, Verfassungsrechtliche Aufsätze, 181-231, at 217-24; Carl Schmitt, 'Die Auflösung des Enteignungsbegriffs' in Schmitt, Verfassungsrechtliche Aufsätze, 110-23.

34 Schmitt, Legality and Legitimacy, 17-26. $\quad{ }^{35}$ Schmitt, Political Theology, 5-15.

36 Schmitt, Dictatorship, 80-147. 
which uses its unbounded discretion to create a situation of normality or homogeneity - if necessary by the use of force which eliminates dissent. This activity need not be conservative. It may well turn out to be revolutionary. He who decides on the absolute exception also decides what is to be regarded as normal or exceptional and thus defines what kind of homogeneity is to be brought about. ${ }^{37}$

It would be wrong, however, to think of the sovereign's decision as a top-down imposition of authority. For the sovereign to be successful in the attempt to define normality, the decision must express some widely shared substantive identity which is prior to the law and to the state as a legal expression of community. This identity will become political, Schmitt argues, only if a sufficient number of members of a society are willing to fight and die for the defence of that identity against those whom they perceive as its internal and external enemies. ${ }^{38}$

Schmitt's famous criterion of the political is motivated by the aim to portray the constitution of political community as a process which does not involve legality. Schmitt insists that we cannot define 'the political' with reference to the state, for example, as the fight for control over the state. ${ }^{39}$ The state is inextricably bound up with law; it is an institution constituted by rules of legality. If sovereignty and political community are to be prior to law, then sovereignty and political community must be explicable in terms which do not make reference to the state. It must be possible to explain what a political community is, what distinguishes it from other kinds of community, without taking resort to the implicitly legal notions which are the building blocks of our idea of the state: representation, authorization or the idea of a social contract. This is why Schmitt claims that political community is defined by a pre-legal distinction between friend and enemy. ${ }^{40}$ In successfully dividing society into those who support or reject a decision on the exception, and the definition of normality implied by it, the decision on the exception proves that some shared identity has political quality. It does this by forcing people to take sides, to reveal themselves as friends or enemies in a space outside the law relative to the identity highlighted by the sovereign as a marker of political community. ${ }^{41}$

\footnotetext{
37 Schmitt, Political Theology, 13. $\quad{ }^{38}$ Schmitt, Concept of the Political, 25-7.

39 Ibid., 19-25.

${ }^{40}$ It is also why Schmitt emphasizes that an exercise of constituent power is not bound to any particular legal form. See Schmitt, Constitutional Theory, 130-5.

${ }^{41}$ Schmitt, Concept of the Political, 46-7, on the internal enemy.
} 
A group exists as a political community, Schmitt concludes, as long as (and only as long as) it remains capable of taking a decision on the exception and thus to determine its own political identity. ${ }^{42}$ The decision must be the group's own, not one imposed on the group, whether by force or fraud, by its internal or external enemies. Since every decision on the exception draws a boundary between insiders and outsiders, we can also conclude that a group will enjoy existence as a political community only as long as it has the power to determine its own membership. It follows that those who would attempt to subject a political community to some normative standard of inclusion must be seen as attacking its very existence. And a political community, Schmitt argues, must take itself to have a right to reject and to repel their proposals. $^{43}$

In making this claim, Schmitt does not put forward a view about the instrumental value of political community to its members. He does not argue, say, that membership in a political community which enjoys unrestricted self-determination, including the right to redraw its boundaries as it sees fit, is necessary to realize the good life of individuals and that we should therefore recognize each political community's right to determine its own identity. Any such argument would raise the obvious question of why it should be morally permissible for the decision on the exception to pre-emptively exclude those who are defined by the sovereign as internal enemies from the community.

Schmitt addresses himself only to those who already see each other as the true members of some pre-legal political community, or who can be brought so to see themselves, and who already accept the claim that nothing should be allowed to thwart that group's political existence. ${ }^{44}$ Schmitt's aim is simply to raise awareness, amongst readers or listeners who fit that description, of the danger that an unconditional commitment to legality may threaten the existence of the political community to which they take themselves to belong and which they hold to be supremely valuable. Or, to put the point slightly differently, Schmitt is trying to stop his audience from confusing their political community with their state. The latter is a legally constructed entity whose rules are likely to give some sort of standing, perhaps even citizenship, to some who do not truly belong to the political community and who undermine the homogeneity which is the necessary condition of legal determinacy. ${ }^{45}$

42 Ibid., 50-3. $\quad 43$ Ibid., 45-50. $\quad{ }^{44}$ Ibid., 26-7. ${ }^{45}$ Schmitt, Leviathan, 41-52. 
Hence, one should recognize that the concrete will of the political community, as manifested in the decision on the exception, must have the power to prevail against the rule-based authority of the state.

In raising awareness of the conditions of preservation of the political community, Schmitt takes himself to be defending democracy. Pretending to take his cues from Rousseau, Schmitt defines democracy as the identity of ruler and ruled, and he argues that the successful sovereign decision on the exception is the most perfect realization of that identity. ${ }^{46}$ In taking a decision on the absolute exception, a pretender to sovereign authority proposes to a group of people to define their political identity in a certain way. He or she will be successful, though, as already pointed out, only if a sufficient number of the addressees concur with his or her distinction between friends and enemies and are motivated to draw the requisite practical conclusions from it. Hence, the sovereign decision on the exception is really a communal decision. Through that decision, a group manifests its existence as a political community in the willingness of its members to treat some characteristic which they share as a political identity, an identity for which one must be willing to fight and die.

A successful sovereign decision on the exception, Schmitt suggests, is the paradigmatic case of collective self-government. The sovereign, in taking the decision on the exception, is not a representative whose will is imputed by fiction to all those who are regarded as members of an artificial social body, though their individual wills may differ from that of the sovereign. The successful sovereign decision, rather, is the concrete manifestation, according to Schmitt, of the real, the unanimous will of a people - the only one there can be. ${ }^{47}$ And it is only as long as the identity which finds political expression in it is preserved, in the day-to-day business of constituted, legally regulated politics, that the law remains legitimately applicable. ${ }^{48}$

46 For Schmitt's theory of democracy, see Schmitt, Crisis of Parliamentary Democracy, 8-15, 22-32; Schmitt, Constitutional Theory, 255-67.

47 Ibid., 75-7, 125, 130-2, 136; Schmitt, Concept of the Political, 27.

48 Schmitt's critique of the Weimar constitution claims that the revolution of 1918 had failed to bring about homogeneity. See Schmitt, Constitutional Theory, 82-8, 154-6. Once the Weimar Republic entered its political crisis, Schmitt argued that a renewed exercise of sovereign authority might be called for to solve the problem. See Schmitt, Legality and Legitimacy, 85-94. 


\section{The failure of Schmitt's normative argument}

We are now in a position to offer an assessment of Schmitt's normative claim. Does Schmitt present a convincing argument for the claim that the legitimate applicability of law requires the existence of a sovereign authority?

It is not difficult to see why Schmitt's theory of popular sovereignty is problematic. Schmitt claims that the sovereign's decision on the exception perfectly realizes the democratic identity of ruler and ruled. But this is so only for the trivial reason that any successful decision on the exception draws the boundaries of political community in such a way as to remove from the polity all those who do not follow and support the sovereign's interpretation of its identity. The identity of ruler and ruled which is manifest in the successful decision on the exception is an artefact of antecedent exclusion, in a space outside of law, of all interesting political difference and all deep dissent.

The view that democracy is the identity of ruler and ruled is normally understood to raise a more interesting claim. Rousseau, for instance, argues that democratic institutions, attitudes and practices will allow citizens who differ in their private interests and their social identities to benefit from the realization of common interests and to do so in a way that ensures a proper respect for the individual freedom of each. For Rousseau, democratic identity results from the reasonable acceptability to all of laws produced by a legal and constitutional system which successfully implements the ideal of civic equality. ${ }^{49}$ In Schmitt's view, on the other hand, the identity of ruler and ruled is no longer a goal to be pursued through the instrumentality of settled democratic political practice. Rather, a democratic legal and constitutional system is said to presuppose a political identity which it cannot itself establish or protect and which therefore must be created through the prior dictatorial homogenization of society. The identity of ruler and ruled is no longer realized in a general will but in a particular will which is opposed to the 'crust' of rule-based legality. ${ }^{50}$ For Schmitt, democratic politics in the state of normality does little more than to raise a danger of the corruption of the people's antecedent identity. The most we might ever be able to claim in its favour, in circumstances where the sovereign sees no need to take a decision on the exception, is that it does no harm.

49 See Joshua Cohen, Rousseau: A Free Community of Equals (New York: Oxford University Press, 2010).

50 See Schmitt, Political Theology, 14-5. 
What seems to start with the laudable aim to achieve non-dominating law thus turns into a paean for a collectivist version of the right of the stronger. It may well be true that judicial or legislative decisions, in a society that has been made perfectly homogeneous by sovereign dictatorship, would no longer imply a danger of a domination of the ruled for the simple reason that judicial and legislative decisions could no longer be very controversial among the rulers and the ruled. But this result, to repeat, is achieved only through the prior violent repression and exclusion of all ethical and cultural diversity in the space of exception. The determinacy which results from perfect homogeneity does not make law legitimate as much as it turns the legitimacy of law into something which now can be dispensed with for the reason that all those who are addressed by law, as well as those who make it, share a political identity and will never disagree about the wisdom of any important decision. All others, by definition, are enemies who are outside the polity. The question of how to treat them is not one of legitimacy but of power politics.

Let me emphasize that this critique of Schmitt's theory of popular sovereignty is not primarily a moral critique. The point is not that Schmitt's conception of popular sovereignty is to be regarded as morally incorrect because it licenses disregard of individual rights or minority rights, however true that may be. The point is that Schmitt's argument, though it claims to ground the legitimacy of law in an appeal to popular sovereignty, is selfdefeating as an account of the legitimacy of law.

Imagine that you question the legitimacy of the laws of your society, laws which the sovereign, together with the majority of the members of your community, holds to be legitimately applicable. It would be useless, presumably, for someone to tell you that the laws are legitimate because they express the identity of the people. The fact that you raise a complaint already establishes that you do not belong to the people. If you did belong to the people, on the other hand, you would not raise the complaint, and no explanation of the legitimacy of the law would have to be given to you. Appeals to the legitimacy of the law or the constitution, even if based on the notion of constituent power, become meaningless in Schmitt's framework. Thus, whatever Schmitt thinks he has shown, he cannot have shown that the existence of a sovereign authority is a condition of the legitimate applicability of law. ${ }^{51}$

51 For a fuller statement of this argument, see Lars Vinx, 'The Incoherence of Strong Popular Sovereignty', International Journal of Constitutional Law, 11 (2013), 101. 
It will likely be objected that this criticism misunderstands Schmitt's claim that the legitimate applicability of law requires a sovereign authority. Schmitt, it might be argued, is not concerned with a situation in which the positive law does express the people's identity but with a case where it does not. If law does not express the identity of the people, it will run counter to and frustrate the people's collective self-determination and thus be illegitimate. This is what happens, for instance, when a parliamentary legislature is captured by partial interests which have the power to bring about legislative decisions that frustrate the true will of the people, as expressed in a past decision on the exception. The claim that the legitimate applicability of law requires the existence of a sovereign authority is to be understood as the claim that such a situation can only be prevented where there is a sovereign who can switch the law off. ${ }^{52}$

This re-interpretation of the claim that sovereignty is a pre-condition of the legitimate applicability of law concedes that Schmitt is not concerned to offer reasons to a dissenting minority why it should defer to the law though it rejects the law's content. He is now portrayed as concerned, rather, to warn the majority against accepting the deliverances of the positive legal system's procedures as final. In doing so, the majority would alienate its collective autonomy to a positive legal system that provides legal and perhaps political standing and influence to minorities or interest groups which do not share the majority's political identity. The reason why a sovereign authority is needed, then, is not that a sovereign is necessary for the constitution of authoritative law, of law that binds even those who criticize its content. Rather, a sovereign authority is necessary to make sure that the results of legal procedures cannot prevail against the will of the majority of those who claim that they truly belong to the people.

One is inclined to reply that, strictly speaking, it makes no sense for Schmitt to argue that the positive law might frustrate the political self-determination of a people. According to Schmitt, a political community exists if and only if it has the capacity to take a decision on the exception. In this case, though, the law cannot be an impediment to self-determination because the sovereign's decision on the exception can switch it off. If, on the other hand, a group is unable to bring about a decision on the exception, it simply does not exist as a political

52 For this perspective, see Kahn, Political Theology. 
community or a people, and it consequently cannot make any sense to complain that the group's self-determination is impeded by law.

Admittedly, this reply is a little too quick. Schmitt's writings on sovereignty during the Weimar era address a situation in which it is unclear, not least to Schmitt himself, whether there still is a sovereign authority. Put differently, they address a situation in which it is unclear whether the German people still exist as a political community in Schmitt's sense. The answer to these questions must depend on whether the German people, suitably led, are still capable of bringing about a decision on the exception which will, if necessary, prevail against the corrupted positive legality of the Weimar constitution - and whether the German people are still capable of bringing about a decision on the exception depends, in turn, on whether they are willing to support such a decision in light of the conviction that to do so is a pre-condition of the preservation of their collective autonomy. Schmitt's theory of sovereignty, then, is perhaps best seen as an exhortation to Germans to be willing to take the decision on the exception. ${ }^{53}$

This alternative reading of Schmitt's claim that the existence of sovereign authority is a condition of the legitimate applicability of law, in contrast to the one we already rejected, is not self-defeating. But it is also devoid of jurisprudential interest.

We can admit that if political existence is understood in Schmitt's way, it will follow that a political community must always be ready to put aside its commitment to legality if it wants to preserve itself. We can also admit that if political existence, as Schmitt defines it, is desirable, we should fight against an ideology of legalism which wishes to make the law out to be the final arbiter of all social disputes. But what is all that to the law? Why should the law, faced with Schmitt's conception of political existence, abandon its own claim to normative finality? Why should it recognize the Schmittian sovereign's decision on the exception as a legally relevant decision, as a decision about the legitimate applicability of the law? The law, as far as I can see, would have to recognize the sovereign's decision as legally relevant only if the existence of an authority that can take a decision on the absolute exception were necessary for the law to be able to achieve its own essential purposes. But is this the case?

Arguably, a system of law must be backed up by a state to be sufficiently effective to achieve whatever essential purposes it might have.

53 See Schmitt, Crisis of Parliamentary Democracy, 65-76, on the need for a nationalist political myth. 
This was one of the key claims of the classical doctrine of sovereignty. But, as should be clear, the law may very well have the backing of a state even where there is no sovereign capable of taking a decision on the absolute exception. The presence of a sovereign, moreover, is not just unnecessary to secure the law's effectiveness, but it is also likely to frustrate the law's essential purposes on some of the most plausible accounts of what these might be. In recognizing the sovereign's decision as legally relevant, the law would, for example, have to betray the aim which is peculiarly its own according to the classical discourse of sovereignty: namely, the aim to subject social conflict, as far as possible, to peaceful arbitration and to suppress the employment of violence not licensed by the law. We arrive at the same result, obviously, if we follow Fuller and take the law's essential purpose to be the establishment of an inviolable rule of law which will make exercises of power predictable to those affected. ${ }^{54}$ To maintain the claim that the existence of a Schmittian sovereign is necessary to allow the law to achieve its essential purposes, one would, it seems, have to adopt the rather silly view that the essential purpose of law consists in not getting in the way of the decision on the exception.

Legal positivists who question the claim that the law has essential purposes are unlikely to arrive at a different conclusion. In recognizing the legal relevance of the Schmittian sovereign, the law would, for instance, betray its claim to authority because the law, to claim authority, must take its own decisions to be final. ${ }^{55}$ And if we deny that the law necessarily claims authority, or perhaps that it has any nature at all, there is simply nothing left to build on in trying to establish the jurisprudential relevance of the decision on the absolute exception. Schmitt is not in a position to adopt an instrumental conception of law and to argue that the law's essential purpose is to serve whatever goal the sovereign decides to pursue. The sole purpose of sovereign action, according to Schmitt, is to create homogeneity, and Schmitt is firmly committed to the view that this goal can only be achieved through dictatorial action freed of all legal restraints. Schmitt's conception of sovereignty, I conclude, turns out to be too purely political to be of any jurisprudential relevance.

54 See Lon L. Fuller, The Morality of Law, rev. edn. (New Haven, CT: Yale University Press, 1964).

55 See Joseph Raz, 'Authority, Law, and Morality' in Raz, Ethics in the Public Domain. Essays in the Morality of Law and Politics, rev. edn. (Oxford University Press, 1995), 210-37. 
Schmitt's basic claim is that legality can never make any positive contribution to the legitimate settlement of profound social conflict. He holds, as we have seen, that whenever the answer to a political question is not determined by a background of social agreement, its arbitration in a legally regulated form must involve a hidden exercise of domination under the guise of the rule of law. The liberal idea that suitably constructed legal procedures could ever lead to the fair settlement of political conflict consequently must be a form of false consciousness - a consciousness which must be fought because it might stop the majority, those who truly belong to the people, from asserting their identity against a minority which relies on the rule of law to thwart the strong and subject them to the 'indirect rule' of the weak. Schmitt's point, of course, is not that the rule of the strong is more justifiable, from a moral point of view, than the rule of the weak. His point is simply that as a member of the majority, one should reject the constraints of legality on the majority's power once one has seen them for what Schmitt thinks they are: the impositions of alien groups whose members ought to be regarded as enemies and be done away with in the interest of securing substantive homogeneity.

I hope it is clear that it would be a grave mistake to regard Schmitt's purported rehabilitation of the doctrine of sovereignty as a continuation of the classical discourse of sovereignty. In that discourse, sovereignty and law are seen as essentially arbitrative. Hobbes' sovereign creates unity, and thus peace and security, through representation, not through antecedent exclusion. ${ }^{56}$ His will displaces the wills of those who enter into a social contract; it must be owned, as Hobbes says, even by those who disagree with the wisdom of the sovereign's decisions. ${ }^{57}$ But this displacement, as Schmitt himself complained in his book about Hobbes,

Hobbes, Leviathan, 117-21. It might be objected that Hobbes is not as concerned with peaceful arbitration as I am suggesting. Note, however, that there is not the slightest indication, in Hobbes, of the view that only those who share a certain antecedent identity may become members of the state. Hobbes, admittedly, does not deny that those who violate the social contract may legitimately be treated as enemies. But he clearly takes the view that the default stance of the state must be to extend an offer of inclusion to all who are willing to give peace in exchange for protection, a view that is in stark contrast with Schmitt's views on the constitution of political community. Hobbes also holds - as he makes clear in Chapter 28 of Leviathan - that those who have entered into the social contract are entitled not to be treated as enemies as long as they do not violate the law in outer act. This, again, is a demand of the rule of law that Schmitt is concerned to reject.

57 Hobbes, Leviathan, 120, 124. 
does not destroy the individual will by fusing it into a true collective identity based on a friend-enemy distinction. ${ }^{58}$ It only excludes or preempts it for the time being, for as long as an individual has reason to prefer sovereign protection to the danger of the state of nature. Sovereign representation thus turns plurality into unity without eliminating difference. A modern liberal-democratic state, despite the fact that it does not contain a personal sovereign, does much the same, provided that it has the capacity to finally settle all social conflict.

In Schmitt's theory of sovereignty, by contrast, sovereign representation, as a principle of political unity, is replaced with pre-legal exclusion, and the very possibility of political difference within a legally constituted and pacified political unity is denied. To be more precise, Schmitt's legal theory deliberately attempts to create an attitude, in those to whom it addresses itself, which will make political difference within legal unity impossible. This political project, if I am correct, has little to teach us about the nature of law and the conditions of its legitimacy.

\section{Schmittian sovereignty and the foundations of public law}

The critique of Schmitt presented in this chapter, I hasten to add, is not meant to suggest that we ought to get rid of the notion of popular sovereignty or that we ought to abandon the project of explicating the proper foundations of democratic public law. What I have tried to show is only that Schmitt's attempt to conceive of sovereignty as a personal or 'concrete' authority, prior to both state and law, is unhelpful. Contemporary defenders of popular sovereignty, as well as those searching for foundations of modern public law, are well advised to look for a different source of inspiration. To illustrate this conclusion, I would like to end with a brief discussion of Martin Loughlin's recent attempt to found modern public law on a Schmittian notion of sovereignty.

According to Loughlin, 'the public realm now presents itself as autonomous, it cannot be anchored in either divine law or natural law. The public realm must function according to laws that we have given ourselves.' Loughlin holds, in other words, that the foundations of modern public law cannot and must not be sought in a constitution in natural law. Any such attempt, apart from running the danger of failing 
to convince denizens of a post-metaphysical age, would be exposed to the suspicion of being un-democratic, as it would apparently have to deny the people's power autonomously to determine the conditions of its own political life.

It would be wrong, Loughlin goes on to argue, to react to the failure of the idea of a constitution in natural law by embracing positivism, that is, 'to follow Hobbes' and to conclude that 'law means simply the command of the established law-making authority'. To do this, Loughlin holds, would imply that 'the conditions under which ... law-making authority is exercised are matters of politics that lie beyond juristic knowledge. ${ }^{59}$ Loughlin accuses modern positivists such as Hart and Kelsen of the same mistake which he attributes to Hobbes. They are said to be unable to reflect on the legal constitution of law-making authority because they allegedly hold the constitution of that authority to be 'beyond juristic knowledge'. Schmitt's theory of popular sovereignty, Loughlin suggests, provides a way out of this impasse. It will allow us to understand a democratic constitution as the product of the validating choices of a perfectly autonomous constituent power.

It is not quite clear whether Loughlin's critique of positivism is meant to be theoretical or normative. On a theoretical reading, Loughlin complains that positivism provides an incomplete understanding of public law. However, if the critique of Schmitt presented in this chapter is sound, then this theoretical criticism begs the question. Loughlin assumes that Schmitt's theory of (popular) sovereignty contributes to juristic knowledge and extends it beyond the limits implied by Hartian or Kelsenian approaches. But it is far from clear, as should by now be obvious, whether Schmitt's theory of sovereignty really does this.

Note that Loughlin's attack against Hobbes is confused, since Hobbes acknowledges that the valid exercise of legislative authority is conditioned by a constitution in natural law that, in Hobbes' view, surely is not beyond juristic knowledge. More importantly, Loughlin also misunderstands the legal positivism of Kelsen (or, for that matter, of Hart). According to Kelsen, for instance, laws are not mandatory commands issued by an un-commanded commander. They are rules that authorize organs of state to employ legitimate force. As such, they lay down the conditions, among other things, of the rightful exercise of legislative power. It is therefore plainly false to claim, with Schmitt, that the Pure 
Theory of Law is unable to reflect on the conditions of the rightful exercise of legislative authority. ${ }^{60}$

Loughlin is in a position to chastise modern positivists for not recognizing that there is a law that enables and conditions the exercise of political power only because he wrongly attributes an Austinian picture of law to Kelsen. ${ }^{61}$ This manoeuvre is made all the less convincing by the fact that Loughlin himself seems implicitly attached to an Austinian picture of law. While he attacks Austin's claim that all law is sovereign command, Loughlin at times seems to express his agreement with the view that, in a modern legal order, all positive law is sovereign command. ${ }^{62} \mathrm{He}$ also holds, like Schmitt, that droit politique, the metapositive law which is said to constitute the state, is not judicially enforceable and that its content, since it cannot be drawn from a science of public right, is wholly subject to the materially unrestricted choices of the (popular) sovereign. ${ }^{63}$ In substance, this is an Austinian picture of the relation between the sovereign and the law, veiled by the rhetorical choice to refer to what Austin would have called constitutional morality as droit politique.

This rhetorical choice, however, begs the question why droit politique deserves to be recognized as a species of law. The only convincing answer I can think of is that it consists of rules which - while they are not commands backed by threats - condition the valid exercise of public power. But if that is what makes droit politique into law, it is perfectly possible, as Kelsen, in particular, has shown, to conceive of it as part and parcel of the system of positive law - since the system of positive law as a whole is best understood as a system of authorizations for the use of force - and to make it judicially enforceable by giving judges the power to void purported acts of public power which lack adequate legal authorization. ${ }^{64}$

The real issue here, I submit, is not that modern, 'normativist' positivists have no coherent story about the foundations of public law or that

60 See Hans Kelsen, 'Who Ought to be the Guardian of the Constitution?' in The Guardian of the Constitution, 174-221.

${ }^{61}$ For Kelsen's relationship to Austin's command theory, see Lars Vinx, 'Austin, Kelsen and the Model of Sovereignty: Notes on the History of Modern Legal Positivism' in Michael Freeman and Patricia Mindus (eds.), The Legacy of John Austin's Jurisprudence (Dordrecht, Netherlands: Springer, 2013), 51-71.

${ }^{62}$ Loughlin, Foundations of Public Law, 186, 196, 209-16. $\quad{ }^{63}$ See, e.g., ibid., 229.

${ }^{64}$ Hans Kelsen, 'The Nature and Development of Constitutional Adjudication' in The Guardian of the Constitution, 22-78. 
they cannot offer any substantive discussion of the problem of the legality of acts of state. What really bothers Loughlin (and others) is that modern positivist approaches to public law deny the jurisprudential relevance of a certain kind of popular sovereign. Kelsen refuses to admit that a popular sovereign transcendent to all law, and completely unbound from it, could be more than a de facto power. He denies that the decisions of such a sovereign could ever be regarded as a validating source of constitutional legality. The claim that this stance leads to an incomplete understanding of the law rests on a normative criticism, on the claim that rule-based positivism systematically obscures the ground of the legitimacy of law. Authors who, like Loughlin, are concerned to resurrect Schmitt's strong notion of popular sovereignty hold that there can be no true collective freedom unless the established legal and political system is made subject to the legally untrammelled choices of a meta-legal popular sovereign. ${ }^{65}$

Loughlin, then, must establish, like Schmitt, that his adaptation of a strong notion of popular sovereignty is required from a normative point of view, that reliance on that conception of sovereignty is necessary to explain the legitimate constitution of legal order, that it is necessary to allow us to conceive of legal order as the product of a legitimating collective choice. In the absence of a constitution in natural law, however, it is difficult to see what could constitute a constituent power prior to all law, other than Schmitt's distinction between friend and enemy. And that distinction, as we have seen, apart from implying a rather problematic understanding of democracy, systematically fails to account for the legitimacy of law.

The reason for this failure, I suspect, is not that Schmitt did not understand the limitations of his own theory. It is that Schmitt was not really trying, despite his protestations to the contrary, to explain the legitimacy of law. Schmitt's clever and inventive theory of sovereignty is a tactical deception, designed to misdirect those who are interested in understanding the foundations of a democratic constitution on to an authoritarian path. It is time for theorists of public law to stop falling for it.

${ }^{65}$ See also Hans Lindahl's contribution to this volume (Chapter 3); Panu Minkkinen, 'Political Constitutionalism versus Political Constitutional Theory: Law, Power and Politics', International Journal of Constitutional Law, 11 (2013), 585. It should go without saying that Schmitt's project of resurrecting the absolutist Obrigkeitsstaat in pseudodemocratic garb is not the only way to understand popular sovereignty. 